\title{
Genetic parameters of milking frequency and milk production traits in Canadian Holsteins milked by an automated milking system
}

\author{
M. Nixon, ${ }^{*}$ J. Bohmanova, ${ }^{*}$ J. Jamrozik, ${ }^{*}$ L. R. Schaeffer, ${ }^{*}$ K. Hand, $†$ and F. Miglior $¥ \S^{1}$ \\ ${ }^{*}$ Centre for Genetic Improvement of Livestock, University of Guelph, Guelph, Ontario, Canada, N1G 2W1 \\ †CanWest DHI, Guelph, Ontario, Canada, N1K 1E5 \\ fDairy and Swine Research and Development Centre, Agriculture and Agri-Food Canada, Sherbrooke, Quebec, Canada, J1M 1 Z3 \\ §Canadian Dairy Network, Guelph, Ontario, Canada, N1K 1E5
}

\section{ABSTRACT}

Twice-a-day milking is currently the most frequently used milking schedule in Canadian dairy cattle. However, with an automated milking system (AMS), dairy cows can be milked more frequently. The objective of this study was to estimate genetic parameters for milking frequency and for production traits of cows milked within an AMS. Data were 141,927 daily records of 953 primiparous Holstein cows from 14 farms in Ontario and Quebec. Most cows visited the AMS $2(46 \%)$ or 3 $(37 \%)$ times a day. A 2-trait [daily (24-h) milking frequency and daily (24-h) milk yield] random regression daily animal model and a multiple-trait (milk, fat, protein yields, somatic cell score, and milking frequency) random regression test-day animal model were used for the estimation of (co)variance components. Both models included fixed effect of herd $\times$ test-date, fixed regressions on days in milk (DIM) nested within age at calving by season of calving, and random regressions for additive genetic and permanent environmental effects. Both fixed and random regressions were fitted with fourth-order Legendre polynomials on DIM. The number of cows in the multiple-trait test-day model was smaller compared with the daily animal model. Heritabilities from the daily model for daily (24-h) milking frequency and daily (24-h) milk yield ranged between 0.02 and 0.08 and 0.14 and 0.20 , respectively. Genetic correlations between daily (24-h) milk yield and daily (24-h) milking frequency were largest at the end of lactation (0.80) and smallest in mid-lactation (0.27). Heritabilities from the test-day model for test-day milking frequency, milk, fat and protein yield, and somatic cell score were $0.14,0.26,0.20,0.21$, and 0.20 , respectively. The genetic correlation was positive between test-day milking frequency and official test-day milk, fat, and

Received September 5, 2008

Accepted February 24, 2009.

${ }^{1}$ Corresponding author: Miglior@cdn.ca protein yields, and negative between official test-day somatic cell score and test-day milking frequency.

Key words: automated milking system, milking frequency, variance component

\section{INTRODUCTION}

In Europe, automated milking systems (AMS) have been commercially available since 1992 . However, the first AMS in North America was installed in 1999. In Canada, AMS are gaining in popularity as hired labor is becoming increasingly unavailable and many producers want to expand their herd without hiring external labor. Furthermore, many producers listed a more flexible lifestyle and more frequent milking as some of the reasons for choosing an AMS (Rodenburg, 2002). With the use of an AMS, milking intervals can vary, and can sometimes be extremely short or extremely long. In a study by Hogeveen et al. (2001), the average milking interval was $9.2 \mathrm{~h}$; that is, a milking frequency of 2.6 times per day. Mačuhová et al. (2003) found the average milking interval was $11.3 \pm 0.5 \mathrm{~h}$, with a milking frequency of 2.1 times per day. With an AMS, cows have a choice of when they want to be milked. Cows that visit the AMS less than twice a day have to be manually brought (or fetched) to be milked. Most producers set the AMS so that milking can be performed only after a minimum interval of $3 \mathrm{~h}$ (Bruckmaier et al., 2001) and set a secondary warning if the cow exceeds a maximum milking interval of (usually) more than $14 \mathrm{~h}$. The secondary warning indicates that the cow needs to be brought to the AMS. Producers report that the effort required to fetch a cow involves identifying them in the milking interval data and then finding and bringing them to the holding area in front of the AMS (Rousing et al., 2005). Rodenburg (2008) reported that $15 \%$ of the cows included in their study needed to be fetched by the producers. Some of the reasons why cows needed to be fetched were lameness, mastitis, injured animal, injured udder or teat, poor teat placement, and cow inexperience. The majority of the producers, however, indicated that most of the cows 
they brought to the robot had no identifiable reason for being fetched (Rodenburg, 2008). Statistics show that the need to fetch cows has a greater incidence in Canada than in Europe, as the number of fetched cows can be as high as 19\% according to data of an AMS herd in Ontario (Rodenburg and Wheeler, 2002). One possibility for this high fetching percentage may be associated with the use of a high-energy TMR feed that is used in North America. Rodenburg and Wheeler (2002) showed that by increasing the frequency of feeding the TMR, there was a slight increase in the cows visiting the AMS, especially in the long-interval cows. However, the high-energy diet fed in North American can also increase lameness in cows, because a relationship has been shown between high-grain diets and laminitis (Espejo and Endres, 2007). Feeding a high-energy TMR diet may thus indirectly cause high fetching rates in AMS herds because of increased lameness.

Food is used as a motivator for cows to visit the AMS. As a result, most producers place high-concentrate pellets within the AMS to entice cows to attend the AMS. A study by Klaas et al. (2003) concluded that highyielding cows receive a large proportion of concentrates during milking in the AMS, which causes them to go to the milking machine more frequently. Consequently, Prescott et al. (1998) found that low-yielding cows did not significantly increase their level of attendance when fed, suggesting that the feed was insufficient to increase the motivation of low-yielding cows to visit the AMS.

Subsequently, if the intervals between cow milkings are too long, it can have a negative effect on milk production (Hogeveen et al., 2001; Ayadi et al., 2003), as well as milk flow rate (Hogeveen et al., 2001). Prolonged milk intervals could be an indication of an underlying health problem with the cow such as lameness, foot problems, udder problems, or overall health. Short milking intervals, on the other hand, were associated with greater milk production per cow per hour (Hogeveen et al., 2001) and increased fat and protein yields (DePeters et al., 1985; Erdman and Varner, 1995). When milking frequencies increased from 2 to 3 times per day an increase in milk yield from 6 to $25 \%$ per lactation was observed (Amos et al., 1985; DePeters et al., 1985; Allen et al., 1986; Klei et al., 1997). The difference in milking intervals may best be explained by cow-related factors, such as their motivation to be milked, their social dominance in the group, their udder pressure, udder depth, milk yield, parity, and health status.

A study by König et al. (2006) found that the heritability of milking frequency was 0.18 , which is enough for direct selection of cows against long milking intervals. That same study revealed a positive genetic correlation between test-day milk yield and test-day milking frequency in the range from 0.46 to 0.57 . This may indicate that higher producing cows visit the AMS more often. In addition, genetic correlations between milking frequency and SCC ranged from 0.01 to 0.06 , which indicates that there was no genetic relationship between these 2 traits.

The objective of this study was to estimate genetic parameters for milking frequency and for production traits of cows milked within an AMS in Canadian Holstein herds.

\section{MATERIALS AND METHODS}

\section{Data}

Fourteen farms using a free-flow traffic (Lely, Maassluis, the Netherlands) robotic milking system in Ontario and Quebec were included in the study. Six farms had 1 AMS per farm, 6 farms had 2 AMS per farm, 1 farm had 3 AMS per farm, and 1 farm had 6 AMS per farm. However, each farm only permitted a cow's access to 1 AMS each. In total, the data were from 953 primiparous Holstein cows with 141,927 daily records (Table 1). Only primiparous cows were included to avoid bias associated with culling. Farms had to have had their AMS for at least $1 \mathrm{yr}$. Most of the data collected were over 13 mo, with a maximum of $22 \mathrm{mo}$ and a minimum of 12 mo. Cows were fed a TMR diet that was pushed up 4 to 6 times per day. All farms had similar robotic training protocols for cows that were inexperienced with the AMS. Only DIM from 5 to 305 were included. Milk yields per milking that were $<1 \mathrm{~kg}$ and $>50 \mathrm{~kg}$ were excluded. Only milk intervals between 3 and $24 \mathrm{~h}$ were used in the study.

Two types of data were used for this study, daily (24-h) records and official test-day records. The daily (24-h) records used were from the AMS herd management program and were recorded for every DIM. These data consisted of daily (24-h) milking frequency and daily (24-h) milk yield only, and did not include fat and protein yields or SCS. Daily (24-h) milk yield was calculated as the sum of cow's milk yields produced within each day in milking as recorded by the herd management program. For example, if a cow produced $13.7 \mathrm{~kg}$ for milking 1 and $13.4 \mathrm{~kg}$ for milking 2, then the daily milk yield would equate to $27.1 \mathrm{~kg}$. Daily (24-h) milking frequency was calculated as the number of milkings on that particular day.

Considerable day-to-day variability was observed for both daily (24-h) milk yield and daily (24-h) milking frequency, which was caused by not averaging the data. Therefore, a smoothing procedure was used to account for the calculated daily milk yield and daily milking frequency, which is recommended by the International Committee of Animal Recording (Miglior et al., 2000). 
NIXON ET AL.

Table 1. Descriptive statistics for data used in the daily model and data used in the test-day model

\begin{tabular}{lcrrl}
\hline Variable & Cows (n) & Records (n) & Mean & SD \\
\hline Daily model & & & & \\
Daily (24-h) milking frequency & 953 & 141,927 & 2.54 & 0.78 \\
Daily (24-h) milk yield (kg) & & & 27.64 & 6.06 \\
Test-day model & 543 & 2,078 & 2.49 & 0.75 \\
Milking frequency & & & 28.38 & 5.92 \\
Milk yield (kg) & & & 0.98 & 0.3 \\
Fat yield (kg) & & & 0.88 & 0.25 \\
Protein yield (kg) & & 2.2 & 1.6 \\
Somatic cell score & & & & \\
\hline
\end{tabular}

Five-day centered averages were used to calculate a daily (24-h) milk yield and daily (24-h) milking frequency. If records were missing, either a 4-d forward or a 4-d lag average was used to calculate daily (24-h) values. If there were no neighboring observations for the daily (24-h) values, the values for that day were not averaged. Classes of DIM were calculated using a span of $30 \mathrm{~d}$, whereas upper and lower tolerance intervals of $2.5 \%(\alpha=0.05)$ for DIM classes by parity were computed. Any data points outside those tolerance levels were removed. Localized regression techniques with adjustment factors were used to calculate the aberrant yields. Any cows with more than 5 data points missing were removed from the study.

The official test-day records, on the other hand, were the same records used for official genetic evaluation and they were selected by matching visit dates from the DHI technician with the same date from the AMS computer. Once the days were matched, milking frequency was obtained from the AMS computer, and therefore it was not official, whereas milk, fat, and protein yields and SCS records were official test-day records obtained from Canadian Dairy Network. At time of the current study, the milk recording protocol to compute test-day milk yield on an AMS farm was to take the milk yield value provided by the robot software on the test-day, and compute it as a 7- or 14-d average of milk yield. CanWest DHI is now moving to a new protocol for AMS farms where exact test-day milk yields are computed at test-day (I. Rumbles, CanWest DHI, Guelph, Ontario, Canada; personal communication). Thus, official test-day yields computed by milk recording (used for the test-day analysis) are likely different from the daily (24-h) yield as computed in the first part of this study used for daily milk analysis.

For the test-day model, any cow with fewer than 2 official test-day records was excluded from the multipletrait test-day model. Thus, only 543 first-parity cows were evaluated by the test-day model (Table 1 ), so the estimates have to be taken with caution.

Similar to Schaeffer et al. (2000), 2 seasons of calving were defined: April through September and October through March. Age classes in months were defined as calving date subtracted from birth date and then divided by 30.4 .

\section{Model}

The first analysis was a 2-trait random regression daily animal model (24-h milk yield and 24-h milking frequency) using daily records obtained from the AMS herd management program. The second analysis was a multiple-trait random regression test-day animal model (milking frequency, milk, fat, and protein yields, and SCS) using official test-day records, which were the same records used for official genetic evaluation.

The model for both analyses was as follows:

$$
\begin{gathered}
y_{i j k l}=H T D_{i}+\sum_{n=0}^{4} \phi(D I M)_{n} A S_{j n} \\
+\sum_{n=0}^{4} \phi(D I M)_{n} a_{k n}+\sum_{n=0}^{4} \phi(D I M)_{n} p e_{k n}+e_{i j k l},
\end{gathered}
$$

where $y_{i j k l}$ is either the daily (24-h) milk yield or daily (24-h) milking frequency for the daily model or testday milking frequency, official test-day milk, fat, protein yields, or SCS for the test-day model; $H T D_{i}$ is the $i$ th herd test-date; $\phi(D I M)_{n}$ is the $n$th covariate of the fourth-order Legendre polynomial evaluated at DIM; $A S_{j n}$ is the fixed regression coefficient of the $j$ th age and season class; $a_{k n}$ is the $n$th random regression coefficient of the additive genetic effect for animal $k ; p e_{k n}$ is the $n$th random regression coefficient of the permanent environmental effect for cow $k$; and $e_{i j k l}$ is the residual effect for each observation. The current study assumed that the environmental effect for milking frequency changed across the lactation, because the learning process of the cow using the AMS is "cow-specific" as some cows learn quicker than others. As a result, the model consists of random regression for permanent environmental effects to account for this fact.

In matrix notation, the model can be written as

$$
\mathbf{y}=\mathbf{X b}+\mathbf{Z a}+\mathbf{W} \mathbf{p}+\mathbf{e},
$$


where $\mathbf{y}$ is the vector of observations (ordered as traits within cow), b includes fixed effects, a includes random genetic regression coefficients, $\mathbf{p}$ includes random permanent environment regression coefficients, $\mathbf{e}$ is the vector of residual effects, and $\mathbf{X}, \mathbf{Z}$, and $\mathbf{W}$ are the incidence matrices. Assume that

$$
\mathbf{y} \mid \mathbf{b}, \mathbf{a}, \mathbf{p}, \mathbf{R} \sim \mathrm{N}(\mathbf{X b}+\mathbf{Z a}+\mathbf{W} \mathbf{p}, \mathbf{R})
$$

and

$$
\operatorname{Var}\left[\mathbf{a}^{\prime} \mathbf{p}^{\prime} \mathbf{e}^{\prime}\right]^{\prime}=\left(\begin{array}{ccc}
\mathbf{G} \otimes \mathbf{A} & 0 & 0 \\
0 & \mathbf{I} \otimes \mathbf{P} & 0 \\
0 & 0 & \mathbf{I} \otimes \mathbf{R}
\end{array}\right),
$$

where $\mathbf{G}$ is the $10 \times 10$ covariance matrix (for the daily model) or $25 \times 25$ covariance matrix (for the test-day model) of the additive genetic regression coefficients, $\mathbf{A}$ is the additive genetic relationship matrix, $\mathbf{I}$ is an identity matrix, $\mathbf{P}$ is the $10 \times 10$ covariance matrix (for the daily model) or $25 \times 25$ covariance matrix (for the test-day model) of the permanent environmental regression coefficients, and $\mathbf{R}$ is the $2 \times 2$ matrix (for the daily model) or $5 \times 5$ full matrix (for the test-day model) of the residual effects on a given day.

The REMLF90 program (Misztal, 1999) was used to estimate the (co)variance components of the 2-trait daily model and the multiple-trait test-day model.

\section{RESULTS AND DISCUSSION}

\section{Descriptive Statistics}

The average milk yield was similar for both data sets at $28 \mathrm{~kg} / \mathrm{d}$ (Table 1). Milk yield also had a large standard deviation. Averages for milking frequency were similar in both models, averaging 2.5 (Figure 1). Most studies have reported mean frequencies from 2.3 to 2.6 times per day (Hogeveen et al., 2001; Rodenburg and Wheeler, 2002; Rodenburg, 2008). However, most dairy producers are worried about cows that visit the AMS less than twice $(6 \%)$ per day (Figure 1), as these cows have to be fetched and brought to the robotic milking system. Problems arise in cows that are milked only once per day, as SCC tends to increase immediately (Stelwagen and Lacy-Hulbert, 1996), which may mask poor udder health, whereas increased frequency is favorable. By increasing milking frequency from 2 to 3 times per day, an increase in milk yield from 6 to $25 \%$ per lactation is observed (DePeters et al., 1985; Erdman and Varner, 1995; Klei et al., 1997), and there is also a decrease in SCC (Hogeveen et al., 2001).

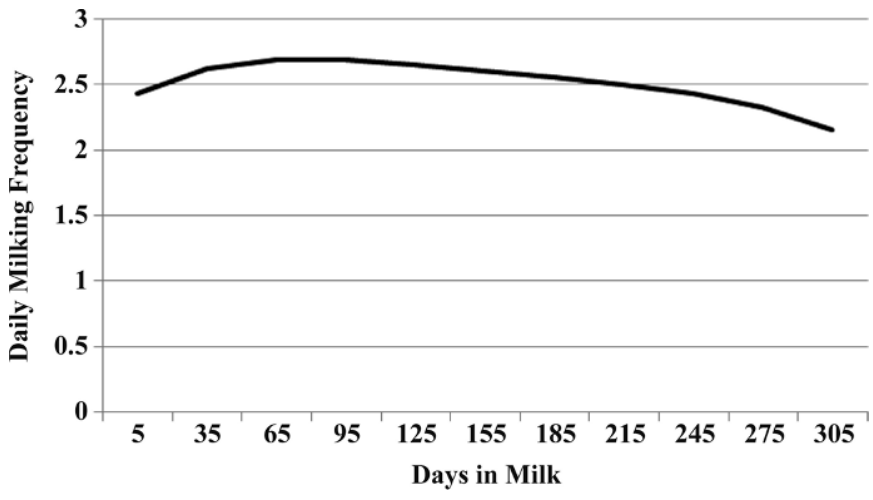

Figure 1. The daily milking frequency by DIM distribution (5 to 305 DIM) for primiparous Holstein cows.

Cows in later stages of lactation tend to go to the AMS less frequently because of a deficiency in udder pressure. The cows that most concern dairy producers are the cows in peak lactation $(<120$ DIM) that are not regularly visiting the AMS, even when food is used as a primary motivator. These cows should have enough udder pressure and hunger as motivation to frequent the AMS more than once per day. Even among cows with $<120$ DIM, a large percentage $(4.5 \%)$ only went to the AMS once per day (Figure 1). The cows that were going once per day with $<120$ DIM had milk yield between 11 and $41 \mathrm{~kg} / \mathrm{d}$.

\section{Variances}

Table 2 shows the genetic, permanent environmental, and residual variances for the daily model (24-h milking frequency and 24-h milk yield) and the test-day model (test-day milking frequency, milk, fat, protein yields, and SCS) for selected DIM. Variances tended to be larger at the beginning and end of lactation, which is probably because of the decrease in the number of records that correspond to these time periods, and are possible artifacts of Legendre polynomials. The residual variance was assumed constant throughout the lactation, which differs from the Canadian test-day model for which the residual variances are broken down into different classes across the lactation (Schaeffer et al., 2000).

Both daily (24-h) and test-day milking frequency were highly variable, as cows tend to have different motivators to go to the AMS. The desire to be milked is one of the motivators for cows to visit the AMS. Rathore (1982) found that high-yielding cows tended to enter the milking parlor earlier than low-yielding cows, suggesting that the relief in easing udder pressure through milking is a reward for the cow to be milked. However, food is a significantly more rewarding motivator. 
Table 2. Genetic, permanent environment (PE), and residual variances for daily (24-h) milking frequency and daily (24-h) milk yield on selected DIM

\begin{tabular}{|c|c|c|c|c|c|c|}
\hline \multirow[b]{3}{*}{ DIM } & \multicolumn{6}{|c|}{ Two-trait model } \\
\hline & \multicolumn{3}{|c|}{ Milk yield } & \multicolumn{3}{|c|}{ Milk frequency } \\
\hline & Genetic & $\mathrm{PE}$ & Residual $^{1}$ & Genetic & $\mathrm{PE}$ & Residual $^{1}$ \\
\hline 5 & 13.3 & 67.6 & 3.99 & 0.05 & 0.61 & 0.30 \\
\hline 35 & 5.7 & 31.3 & & 0.01 & 0.26 & \\
\hline 65 & 5.8 & 25.5 & & 0.02 & 0.23 & \\
\hline 95 & 5.2 & 21.7 & & 0.03 & 0.20 & \\
\hline 125 & 4.5 & 21.3 & & 0.04 & 0.18 & \\
\hline 155 & 4.6 & 22.1 & & 0.05 & 0.19 & \\
\hline 185 & 5.4 & 21.8 & & 0.04 & 0.18 & \\
\hline 215 & 6.4 & 22.1 & & 0.03 & 0.18 & \\
\hline 245 & 6.6 & 23.1 & & 0.03 & 0.19 & \\
\hline 275 & 6.2 & 25.3 & & 0.03 & 0.17 & \\
\hline 305 & 19.0 & 84.2 & & 0.06 & 0.46 & \\
\hline
\end{tabular}

${ }^{1}$ Residual variance is equal at every DIM.

\section{Phenotypic Correlations}

Phenotypic correlations were significantly $(P<0.05)$ positive between test-day milking frequency and official test-day milk yield $(0.25)$. On the other hand, phenotypic correlations were significantly $(P<0.05)$ negative between test-day milking frequency and official test-day SCS $(-0.07)$.

\section{Genetic Parameters of the Daily Model}

Heritabilities for daily (24-h) milking frequency and daily (24-h) milk yield for cows in their first parity ranged from 0.02 to 0.08 and from 0.14 to 0.20 , respectively (Figure 2) over the lactation period. Heritabilities for both traits increased as DIM increased, which is similar to what was observed for milking frequency in a study by König et al. (2006), where heritabilities for milking frequency ranged from 0.16 at the beginning of lactation to 0.22 toward the end of lactation. The heritabilities for daily (24-h) milk yield were smaller in the current study compared with other studies, which had heritability for milk yield ranging from 0.40 to 0.59 (Muir et al., 2004; Miglior et al., 2007). The smaller heritabilities found in the current research may be because of the smaller sample size and the use of individual daily records instead of test-day records. Moreover, permanent environmental variances were very large at the beginning and end of lactation, which may account for the decreased heritability observed at the beginning and end of lactation in this study.

Genetic correlations between daily (24-h) milk yield and daily (24-h) milking frequency were largest at the end of lactation (0.80) and lowest in mid-lactation (0.27) (Figure 3). The positive genetic correlation indicates that selection toward increased milk production would also increase the milking frequency. König et al. (2006) reported genetic correlations of milk yield with milking frequency that ranged from 0.46 to 0.57 .

Because the estimates of variance components using daily records were slightly different from those calculated by Canadian Dairy Network for test-day records, we wanted to determine if this difference was a result of the use of daily (24-h) rather than official test-day data or because of the data structure of our data and the small number of data. Therefore, the same model was fitted with official test-day records. A multiple trait random regression model including all traits is an alternative approach for such traits, but this was not applicable to these data, because of the small number of cows and records and risk of model over-parameterization.

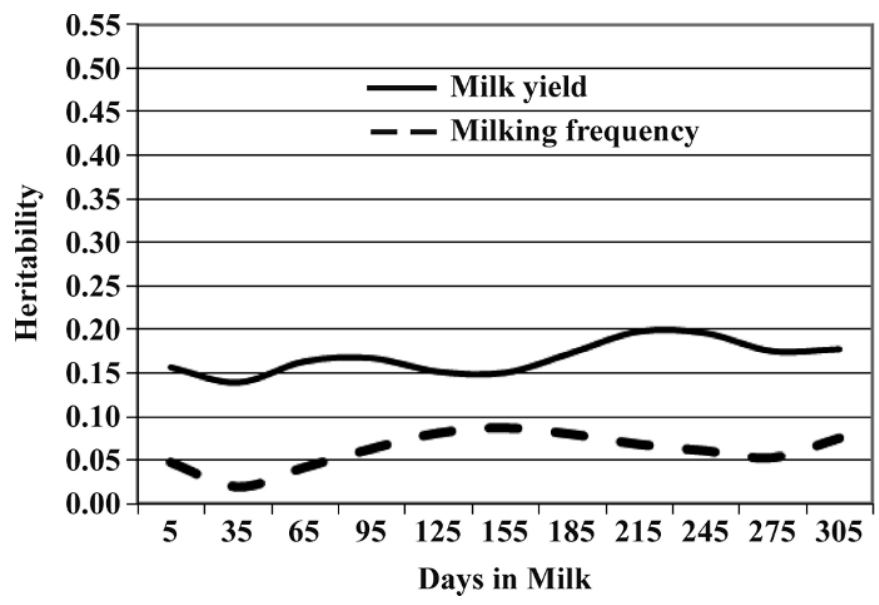

Figure 2. Heritabilities for daily (24-h) milk yield and daily (24-h) milking frequency from the 2 -trait daily animal model. 


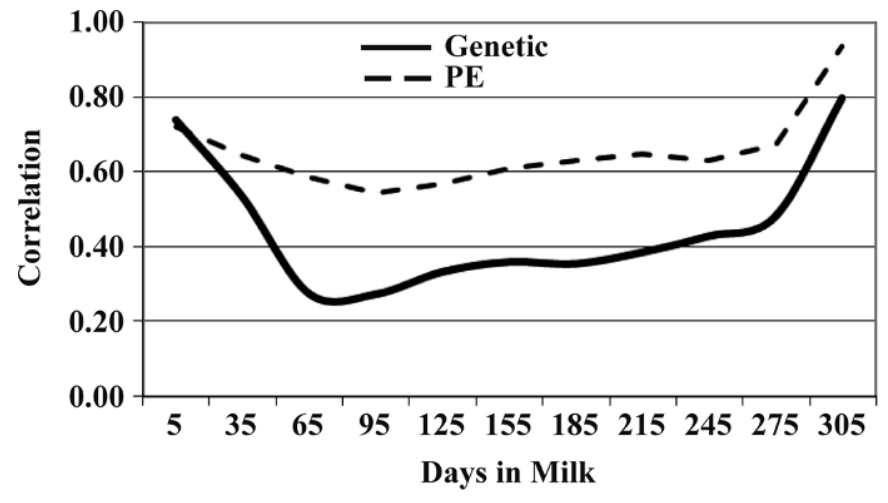

Figure 3. Genetic and permanent environmental (PE) correlations of daily (24-h) milking frequency with daily (24-h) milk yield from the 2 -trait daily animal model.

\section{Genetic Parameters of the Test-Day Model}

Table 3 has average official test-day heritabilities for milking frequency, milk, fat and protein yields, and SCS, which were $0.14,0.26,0.20,0.21$, and 0.20 , respectively. Daily heritability differed throughout lactation (Figure 4). Large increases in daily heritability were noted at 5 and 305 DIM when genetic and permanent environmental variance changed the most. Heritabilities for all traits were largest in early and late lactation, but were stable throughout mid-lactation. Heritability for SCS in Canadian Holstein cows is 0.24, whereas for production traits, heritability ranges from 0.34 to 0.41 (Muir et al., 2004). Thus, the SCS result is in line with official values, whereas heritabilities for production traits from our study tend to be much smaller. The reason could be that our sample includes only cow's milk recorded in AMS herds, or it could be a sign that protocols to collect and compute official test-day yields are not currently accurate in Canada.

Test-day milking frequency had an average heritability of 0.14. Similar heritabilities for milking frequency (mean $=0.18)$ were estimated by König et al. (2006). A similar model for production traits in Canadian Holstein was applied by Muir et al. (2004); in their study, heritabilities were 0.41 for milk yield, 0.33 for fat yield, 0.37 for protein yield, and 0.18 for SCS. Miglior et al. (2007) estimated heritabilities of 0.52, 0.37, 0.42, and 0.19 for milk, fat, and protein yields, and SCS, respectively, for first-parity Quebec Holsteins. The previously estimated heritabilities for production traits were greater than those in the current study, perhaps because of differences in the data or the models. The Canadian test-day model is applied to 4 traits and 3 lactations, but in this study included 5 traits and only first-lactation cows. In addition, the herds with AMS in this study may represent a less genetically variable population of cows than the general Canadian Holstein population.

Genetic correlations between test-day milking frequency and official test-day milk (0.14), official testday fat (0.16), and official test-day protein (0.14) yields were small but positive (Table 4 ), indicating a tendency that cows visiting the AMS more often had greater genetic merit for milk production and suggesting that cows with greater milk, fat, and protein yields will tend to visit the AMS more often. Results obtained in several studies found that cows milking in a milking parlor that switched from 2 to 3 times a day milking had increased milk yield (DePeters et al., 1985; Allen et al., 1986), increased fat yield (DePeters et al., 1985; Allen et al., 1986; Erdman and Varner, 1995), and increased protein yield (DePeters et al., 1985; Erdman and Varner, 1995), demonstrating nongenetic relationships between milk-

Table 3. Genetic, permanent environment (PE), and residual variances for test-day traits including milking frequency; milk, fat, and protein yield; and SCS on selected DIM

\begin{tabular}{|c|c|c|c|c|c|c|c|c|c|c|c|c|c|c|c|}
\hline DIM & \multicolumn{15}{|c|}{ Test-day model } \\
\hline 5 & 0.38 & 0.50 & 0.06 & 28.4 & 52.6 & 1.67 & 0.056 & 0.105 & 0.015 & 0.024 & 0.054 & 0.061 & 2.02 & 1.11 & 0.95 \\
\hline 35 & 0.04 & 0.21 & & 3.4 & 28.0 & & 0.012 & 0.040 & & 0.004 & 0.024 & & 0.63 & 0.77 & \\
\hline 65 & 0.05 & 0.15 & & 3.4 & 19.1 & & 0.009 & 0.022 & & 0.002 & 0.015 & & 0.47 & 0.79 & \\
\hline 155 & 0.07 & 0.11 & & 5.9 & 14.7 & & 0.007 & 0.018 & & 0.004 & 0.015 & & 0.32 & 0.82 & \\
\hline 185 & 0.07 & 0.12 & & 6.1 & 15.2 & & 0.006 & 0.020 & & 0.005 & 0.015 & & 0.41 & 0.85 & \\
\hline 215 & 0.06 & 0.15 & & 6.3 & 16.0 & & 0.006 & 0.022 & & 0.005 & 0.016 & & 0.51 & 0.89 & \\
\hline 245 & 0.05 & 0.19 & & 6.9 & 16.6 & & 0.005 & 0.024 & & 0.005 & 0.016 & & 0.56 & 0.94 & \\
\hline 275 & 0.06 & 0.17 & & 8.0 & 15.3 & & 0.006 & 0.023 & & 0.007 & 0.016 & & 0.45 & 0.79 & \\
\hline 305 & 0.08 & 0.13 & & 11.1 & 14.6 & & 0.023 & 0.027 & & 0.010 & 0.017 & & 0.34 & 0.59 & \\
\hline
\end{tabular}

${ }^{1}$ Residual variance is equal at every DIM. 
Table 4. Average test-day heritabilities (diagonal, in boldface), genetic correlations (above diagonal), and permanent environment (below diagonal) correlations ( $\mathrm{SE}^{1}$ in parentheses) for milking frequency; milk, fat, and protein yields; and SCS

\begin{tabular}{lccccc}
\hline & Milking frequency & Milk & Fat & Protein & SCS \\
\hline Milking frequency & $\mathbf{0 . 1 4}$ & 0.14 & 0.16 & 0.14 & -0.35 \\
& $(0.01)$ & $(0.27)$ & $(0.35)$ & $(0.48)$ & $(0.31)$ \\
Milk & 0.56 & $\mathbf{0 . 2 6}$ & 0.68 & 0.93 & -0.04 \\
& $(0.18)$ & $(0.02)$ & $(0.14)$ & $(0.03)$ & $(0.27)$ \\
Fat & 0.42 & 0.76 & $\mathbf{0 . 2 0}$ & 0.67 & -0.04 \\
& $(0.29)$ & $(0.11)$ & $(0.02)$ & $(0.18)$ & $(0.35)$ \\
Protein & 0.52 & 0.94 & 0.82 & $\mathbf{0 . 2 1}$ & -0.07 \\
& $(0.25)$ & $(0.03)$ & $(0.11)$ & $(0.02)$ & $(0.33)$ \\
SCS & 0.09 & -0.16 & -0.06 & -0.11 & $\mathbf{0 . 2 0}$ \\
& $(0.35)$ & $(0.26)$ & $(0.35)$ & $(0.33)$ & $(0.02)$ \\
\hline
\end{tabular}

${ }^{1}$ All standard errors were calculated using Lo et al. (1992).

ing frequency and yield. Genetic correlation between test-day milking frequency and official test-day SCS was negative $(-0.35)$, indicating that cows that visit the AMS more frequently had smaller SCS. However, König et al. (2006) found no genetic correlation between SCS and milking frequency when cows were milked in an AMS. The genetic correlations involving test-day milking frequency were more variable across 305 DIM than those for production traits (Figure 5), indicating that a large number of animals must be evaluated to make valid interpretations of genetic relationships with milking frequency and other traits. A decrease in SCS was observed with an increase in milking frequency for cows milked in a milking parlor (Allen et al., 1986; Klei et al., 1997).
Large genetic correlations between official test-day milk and official test-day fat yield (0.68), official testday milk and official test-day protein yield (0.93), and official test-day fat and official test-day protein yield (0.67) were observed. Muir et al. (2004) also observed high positive correlations among all yield traits. However, there was a small negative correlation between SCS and the production traits (Table 2), similar to Muir et al. (2004).

\section{CONCLUSIONS}

Both daily (24-h) milking frequency and test-day milking frequency were found to be heritable. A positive correlation was found between both daily (24-h)

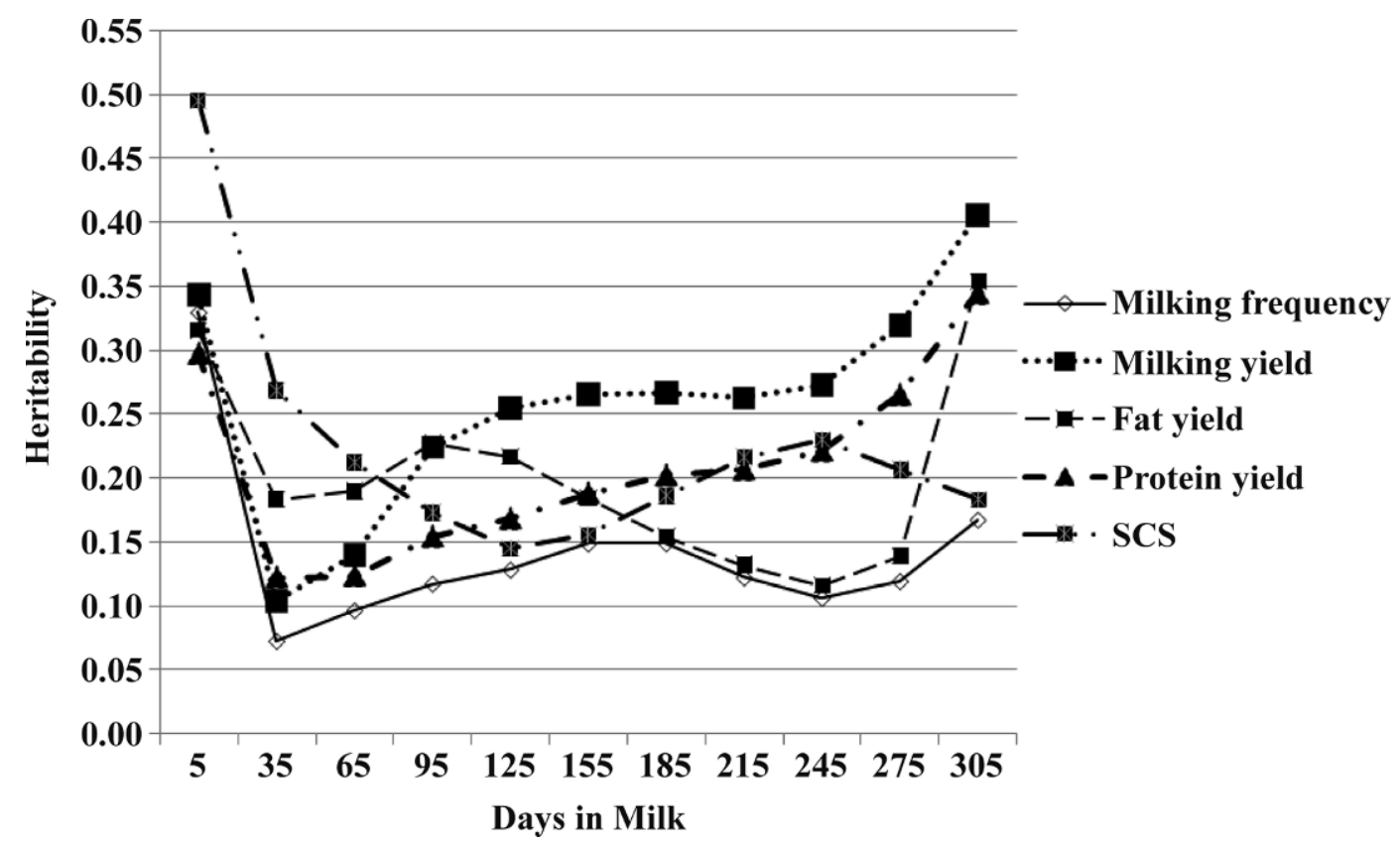

Figure 4. Heritability of test-day milking frequency; official test-day milk, fat, protein yields; and SCS estimated from the test-day model. 


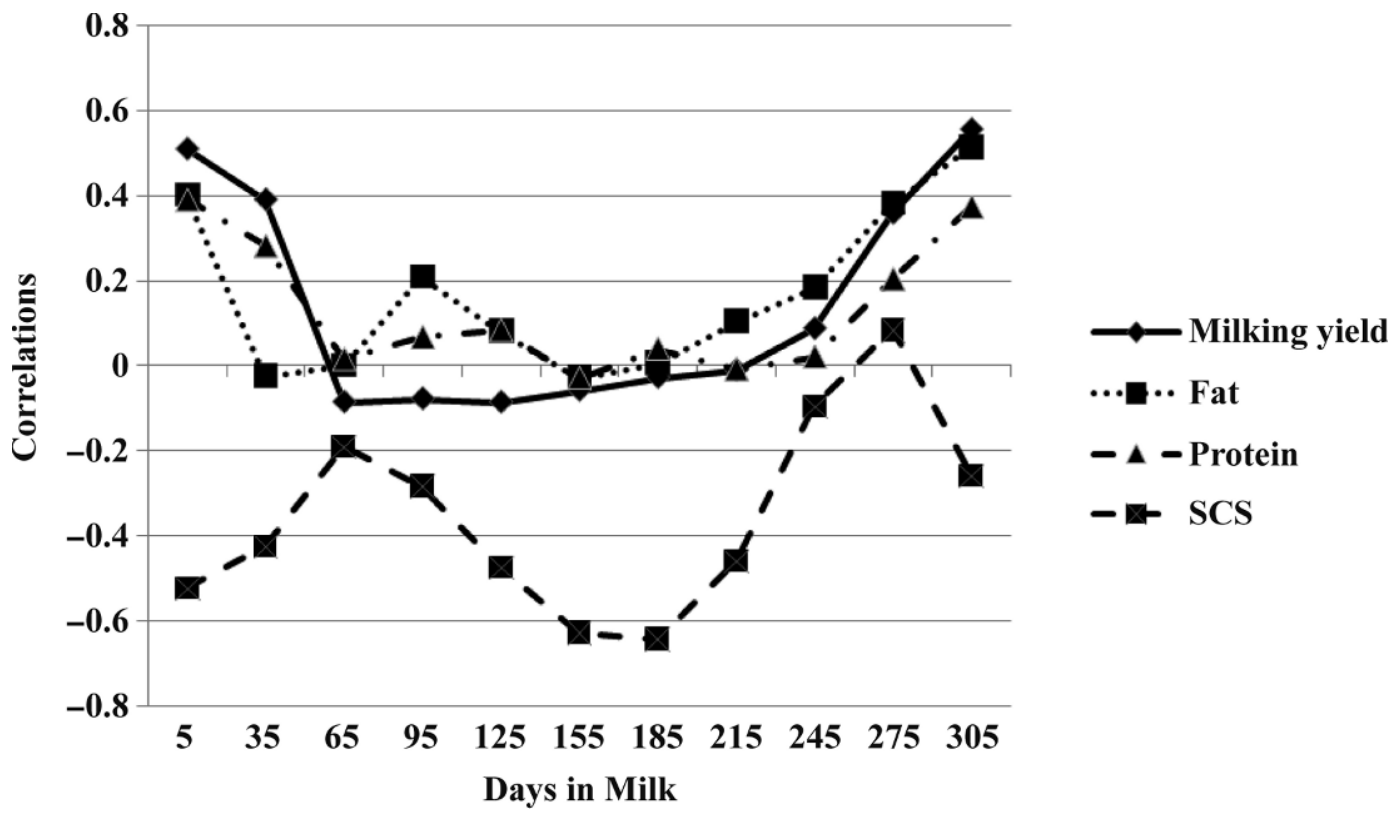

Figure 5. Genetic correlations of test-day milking frequency compared with official test-day milk, fat, and protein yields and SCS estimated from the test-day model.

milk frequency and daily (24-h) milk yield and testday milk frequency with official test-day milk, fat, and protein yields. A negative correlation (favorable) was found between official test-day SCS and test-day milking frequency. These findings suggest that producers with AMS who want to decrease the number of cattle with long milking intervals (thus requiring more labor for fetching) may select indirectly by choosing sires with large EBV for milk yield. Selection for decreased SCS will also have a correlated response in increased milking frequency.

\section{ACKNOWLEDGMENTS}

The authors acknowledge Natural Sciences and Engineering Research Council of Canada, and the DairyGen Council of Canadian Dairy Network who held funds from Lely Canada, DeLaval Canada, and Progressive Dairy Operators (Elora, Ontario, Canada) for funding this project. Appreciation is extended to Ignacy Misztal (University of Georgia, Athens) for providing the use of REMLF90 software. Jack Rodenburg (Ontario Ministry of Agriculture, Food and Rural Affairs, Canada) is acknowledged for helping in the collection and organization of the robotic milking data, and for providing insight into the robotic milking industry. Gratitude is also expressed to the cooperation of the AMS herd owners. Authors are also grateful to the 2 anonymous reviewers for their helpful comments.

\section{REFERENCES}

Allen, D. B., E. J. DePeters, and R. C. Laben. 1986. Three times a day milking: Effects on milk production, reproductive efficiency and udder health. J. Dairy Sci. 69:1441-1446.

Amos, H. E., T. Kiser, and M. Loewenstein. 1985. Influence of milking frequency on productive and reproductive efficiencies of dairy cows. J. Dairy Sci. 68:732-739.

Ayadi, M., G. Caja, X. Such, and C. H. Knight. 2003. Effect of omitting one milking weekly on lactational performances and morphological udder changes in dairy cows. J. Dairy Sci. 86:2352-2358.

Bruckmaier, R. M., J. Macuhova, and H. H. D. Meyer. 2001. Specific aspects of milk ejection in robotic milking: A review. Livest. Prod. Sci. 72:169-176.

DePeters, E. J., N. E. Smith, and J. Acedo-Rico. 1985. Three or two times daily milking of older cows and first-lactation cows for entire lactations. J. Dairy Sci. 68:123-132.

Erdman, R. A., and M. Varner. 1995. Fixed yield responses to increased milking frequency. J. Dairy Sci. 78:1199-1203.

Espejo, L. A., and M. I. Endres. 2007. Herd-level risk factors for lameness in high-producing Holstein cows housed in freestall barns. J. Dairy Sci. 90:306-314.

Hogeveen, H., W. Ouweltjes, C. J. A. M. de Koning, and K. Stelwagen. 2001. Milking interval, milk production and milk flow-rate in an automatic milking system. Livest. Prod. Sci. 72:157-167.

Klaas, I. C., T. Rousing, C. Fossing, J. Hindhede, and T. J. Sørensen. 2003. Is lameness a welfare problem in dairy farms with automatic milking systems? Anim. Welf. 12:599-603.

Klei, L. R., J. M. Lynch, P. A. Barbano, A. J. Lednor, and D. K. Bandler. 1997. Influence of milking three times a day on milk quality. J. Dairy Sci. 80:427-436.

König, S., F. Köhn, K. Kuwan, H. Simianer, and M. Gauly. 2006. Use of repeated measures analysis for evaluation of genetic background of dairy cattle behavior in automatic milking systems. J. Dairy Sci. 89:3636-3644.

Lo, L. L., D. G. McLaren, F. K. McKeith, R. L. Fernando, and J. Novakoski. 1992. Genetic analyses of growth, real-time ultrasound, carcass, and pork quality traits in Duroc and Landrace pigs: II. Heritabilities and correlations. J. Anim. Sci. 70:2387-2396. 
Mačuhová, J., V. Tančin, and R. M. Bruckmaier. 2003. Oxytocin release, milk ejection and milk removal in a multi-box automatic milking system. Livest. Prod. Sci. 81:139-147.

Miglior, F., P. Galesloot, Z. Liu, M. Mathevon, A. Rosati, L. R. Schaeffer, and P. VanRaden. 2000. Report of the ICAR working group on lactation calculation methods: A daily yield lactation survey in diary cattle. Proc. 32nd ICAR Meeting. EAAP Pub. 98:273-274.

Miglior, F., A. Sewalem, J. Jamrozik, J. Bohmanova, D. M. Lefebvre, and R. K. Moore. 2007. Genetic analysis of milk urea nitrogen and lactose and their relationships with other production traits in Canadian Holstein cattle. J. Dairy Sci. 90:2468-2479.

Misztal, I. 1999. REMLF90 Manual. http://nce.ads.uga.edu/ ignacy/ numpub/blupf90/docs/remlf90.pdf. Accessed May 6, 2008.

Muir, B. L., G. Kistemaker, and B. J. Van Doormaal. 2004. Estimation of genetic parameters for the Canadian Test-day Model with Legendre polynomials for Holsteins based on more recent data. A report to the Genetic Evaluation Board, April, 2004. http://cgil uoguelph.ca/dcbgc/Agenda0403/GEB\%20Legendre\%20New\%20 for\%20Holsteins\%20-\%20April\%202004.pdf. Accessed May 28, 2008.

Prescott, N. B., T. T. Mottram, and A. J. F. Webster. 1998. Relative motivations of dairy cows to be milked or fed in a Y-maze and an automatic milking system. Appl. Anim. Behav. Sci. 57:23-33.
Rathore, A. K. 1982. Order of entry at milking and its relationship with milk yield and consistency of the order. Appl. Anim. Ethol. 8:45-52.

Rodenburg, J. 2002. Robotic Milkers: What, where and... how much? Ohio Dairy Management Conference.

Rodenburg, J. 2008. Robotic Milking Systems: Are they the wave of the future? Paper prepared for the Western Canadian Dairy Seminar. 20:35-54.

Rodenburg, J., and B. Wheeler. 2002. Strategies for incorporating robotic milking into North American herd management. Pages III-18 to III-32 in Proc. 1st North Am. Conf. Robotic Milking. Wageningen Pers, Wageningen, the Netherlands.

Rousing, T., J. H. Badsberg, I. C. Klaas, J. Hindhede, and J. T. Sørensen. 2005. The association between fetching for milking and dairy cows' behavior at milking and avoidance of human approach - An on farm study in herds with automatic milking systems. Livest. Sci. 101:219-227.

Schaeffer, L. R., J. Jamrozik, G. J. Kistemaker, and J. Van Doormaal. 2000. Experience with a test-day model. J. Dairy Sci. 83:11351144 .

Stelwagen, K., and S. J. Lacy-Hulbert. 1996. Effect of milking frequency on milk somatic cell count characteristics and mammary cell damage in cows. Am. J. Vet. Res. 57:902-905. 